J. Dairy Sci. 95:2585-2594

http://dx.doi.org/10.3168/jds.2011-4788

(C) American Dairy Science Association ${ }^{\circledR}, 2012$.

\title{
Effects of feeding a calf starter on molecular adaptations in the ruminal epithelium and liver of Holstein dairy calves
}

\author{
A. H. Laarman, ${ }^{\star}$ A. L. Ruiz-Sanchez, ${ }^{*}$ T. Sugino, + L. L. Guan, ${ }^{*}$ and M. Oba* \\ *Department of Animal, Food and Nutritional Science, Faculty of Agricultural, Life and Environmental Sciences, University of Alberta, Edmonton, \\ Canada T6G 2P5 \\ †Department of Bioresource Science, Graduate School of Biosphere Science, Hiroshima University, Higashi-Hiroshima, Japan 739-8528
}

\section{ABSTRACT}

The objective of this study was to elucidate the effect of feeding a calf starter on the volatile fatty acid (VFA) profile in the rumen and on expression of genes involved in epithelial intracellular $\mathrm{pH}$ regulation, butyrate metabolism, and hepatic urea cycle during the weaning transition. Twenty Holstein bull calves were fed either milk replacer and hay (MR) or milk replacer, hay, and a commercial texturized calf starter $(\mathrm{MR}+\mathrm{S})$ in a randomized complete block design. All calves were fed $750 \mathrm{~g} / \mathrm{d}$ of milk replacer as the basal diet. Calves on the $\mathrm{MR}+\mathrm{S}$ treatment were also fed starter ad libitum, and the energy intake of calves within blocks was maintained by supplementing the MR group with extra milk replacer that was equivalent to the energy intake from calf starter. Calves were killed $3 \mathrm{~d}$ after they consumed $680 \mathrm{~g} / \mathrm{d}$ of calf starter for 3 consecutive days. Calves fed $\mathrm{MR}+\mathrm{S}$ had higher VFA concentrations in the rumen $(99.1 \pm 8.1$ vs. $64.6 \pm 8.6 \mathrm{mM})$ and a higher molar proportion of butyrate $(15.6 \pm 1.7$ vs. $7.9 \pm 1.9 \%)$ than calves fed MR. Relative abundance of mRNA for monocarboxylate transporter isoform 1 was higher (1.45 vs. 0.53 ), and that of $\mathrm{Na}^{+} / \mathrm{H}^{+}$exchanger isoform 3 (0.37 vs. 0.82 ) and 3-hydroxy-3-methylglutaryl synthase isoform 1 (0.40 vs. 0.94) lower for the MR+S treatment compared with the MR treatment. In the liver, relative mRNA abundances of argininosuccinate synthetase isoform 1 (2.67 vs. 1.56), argininosuccinate lyase (1.44 vs. 0.99), and arginase isoform 1 (3.21 vs. 1.74) were greater for $\mathrm{MR}+\mathrm{S}$ than for $\mathrm{MR}$ calves. Calf starter consumption appeared to increase fermentation in the rumen and affected expression of genes involved in cholesterol synthesis and intracellular $\mathrm{pH}$ regulation in ruminal epithelium, and those involved in urea cycle in the liver.

Key words: calf starter, rumen epithelium, gene expression

Received July 30, 2011.

Accepted January 9, 2012.

${ }^{1}$ Corresponding author: masahito.oba@ales.ualberta.ca

\section{INTRODUCTION}

Neonatal calves do not have a functioning rumen. When calves begin to consume solid feed, the weight of the rumen as a fraction of live weight increases (Walker and Walker, 1961). Fermentation of calf starter increases ruminal concentrations of VFA, especially propionate and butyrate (Warner et al., 1956; Stobo et al., 1966), which most potently stimulate papillae development in the rumen (Sander et al., 1959). To foster rumen development, it is recommended that calves maximize intake of easily fermentable calf starter (NRC, 2001), which promotes ruminal papillae development (Stobo et al., 1966). Rapid ruminal fermentation can decrease rumen $\mathrm{pH}$, which is associated with detrimental health effects in mature ruminants (Nocek, 1997). However, feeding calf starter does not appear to affect rumen pH in dairy calves (Laarman and Oba, 2011), which may indicate that the rumen epithelium adapts to calf starter fermentation. The specific adaptations to increasing fermentation in the rumen, however, are not well understood.

The neonatal rumen epithelium relies heavily on glucose as a metabolic fuel, but the mature rumen epithelium derives most of its energy from VFA oxidation (Rémond et al., 1995), and it is around the time of weaning that major changes in preferred metabolic substrates occur (Baldwin and Jesse, 1992). Although the effects of calf starter fermentation on morphological development of the rumen are well accepted (Warner et al., 1956), effects of calf starter consumption on metabolic adaptations of ruminal epithelium are not well understood. Mature cows absorb 60 to $80 \%$ of all VFA and approximately $50 \%$ of protons across the rumen wall (Allen, 1997), and the VFA transport capacity needs to increase to accommodate greater fermentation in the rumen. The rumen epithelium does not only transport VFA, but also metabolizes some of it, especially butyrate. Between 75 and $90 \%$ of absorbed butyrate is metabolized in the ruminal epithelium, and $83 \%$ of metabolized butyrate is converted into ketone bodies (Rémond et al., 1995). The neonatal rumen, however, 
is nonketogenic (Lane et al., 2002); thus, the ketogenic capacity of the ruminal epithelium develops over time.

Furthermore, calf starter fermentation in the rumen increases feed protein degradation to ammonia, and absorbed ammonia needs to be detoxified via the hepatic urea cycle. During weaning in calves, urine urea concentrations have been shown to increase following increased concentrate consumption (Hugi and Blum, 1997), suggesting changes in urea cycle activity. Although age has shown to affect activity and mRNA abundance of hepatic enzymes involved in the urea cycle (Takagi et al., 2008), the effect of feeding calf starter on these genes is not well understood.

Good understanding of metabolic changes, including those at the molecular level, is important to develop proper nutritional management programs for calves during the weaning transition. However, the metabolic adaptations of the rumen epithelium and liver during the weaning transition have not been well investigated. Moreover, the role of diet, energy intake, and age in metabolic adaptations is unclear. The objective of this study was to examine expression of genes during the weaning transition and distinguish those primarily affected by consumption of calf starter and those primarily affected by age or energy intake. We hypothesized that the calf starter fermentation in the rumen would affect the expression of genes involved in butyrate metabolism and regulation of intracellular $\mathrm{pH}\left(\mathbf{p H}_{\mathbf{i}}\right)$ in ruminal epithelium and the urea cycle in the liver.

\section{MATERIALS AND METHODS}

\section{Animals and Diets}

All procedures for the animal study were approved by the Livestock Animal Care and Use Committee of the University of Alberta, using the guidelines of the Canadian Council for Animal Care (Ottawa, ON) and carried out as described previously (Laarman and Oba, 2011). Twenty Holstein bull calves were obtained in October $2008(\mathrm{n}=10)$ and May $2009(\mathrm{n}=10)$, from a commercial dairy farm, at $46.7 \pm 1.0 \mathrm{~kg}$ of BW and 13.1 $\pm 0.4 \mathrm{~d}$ of age. Prior to arrival, calves were individually housed and given up to $4 \mathrm{~L}$ of whole milk daily but had no access to calf starter. After calves were moved to the Metabolic Unit at the University of Alberta Edmonton Research Station, all animals were housed in 3.05- $\times$ 3.66-m individual pens with wood shavings for bedding. All animals had ad libitum access to water and chopped hay throughout the study. Calves obtained in October 2008 were fed chopped timothy hay $(7.7 \%$ CP, $65.6 \%$ NDF), whereas calves obtained in May 2009 were fed chopped mixed legume hay $(15.0 \% \mathrm{CP}, 56.8 \% \mathrm{NDF})$. Calves were blocked into pairs using starting date of the study and BW as blocking criteria. In each pair-fed block, one calf was assigned to milk replacer (MR) treatment and the other calf was assigned to milk replacer and starter $(\mathbf{M R}+\mathbf{S})$ treatment.

All calves received milk replacer $(22 \% \mathrm{CP}, 17 \%$ fat, and $45 \%$ lactose; High Performance Milk Replacer, Grober Nutrition, Cambridge, ON, Canada) at $750 \mathrm{~g} / \mathrm{d}$ (12.5\% wt/vol) as the basal diet. The $\mathrm{MR}+\mathrm{S}$ calves were also offered a commercial texturized calf starter containing canola meal, soybean meal, wheat, barley, corn, peas, vitamins, and minerals with $23 \% \mathrm{CP}$ and $4 \%$ ether extract (EE) as the guaranteed minimum (19.5\% NDF, $27.1 \%$ starch; Wetaskiwin Co-Op Country Junction, Wetaskiwin, AB, Canada) ad libitum. The ME of the milk replacer and starter, respectively, were calculated using the formulas (NRC, 2001) below:

$$
\begin{gathered}
\mathrm{ME}=0.93 \times(0.057 \times \% \mathrm{CP}+0.092 \times \% \text { fat } \\
+0.0395 \times \% \text { lactose }) \\
\mathrm{ME}=[(1.01 \times \mathrm{DE})-0.45]+[0.0046 \times(\% \mathrm{EE}-3)], \\
\text { where digestible energy }(\mathrm{DE})=0.7 \\
\times[(0.057 \times \% \mathrm{CP})+(0.092 \times \% \mathrm{EE}) \\
\quad+(0.0415 \times \% \text { carbohydrates })]
\end{gathered}
$$

For the $\mathrm{MR}+\mathrm{S}$ calves, starter intake was recorded daily, and ME intake from starter was calculated. The MR calves were fed additional milk replacer to supply $\mathrm{ME}$ equivalent to that of calves consuming starter in the same block. Therefore, calves within each block were expected to have similar ME intake, attenuating the confounding effect of energy intake within blocks on results. Milk replacer was offered twice daily in 2 equal portions at 0515 and $1515 \mathrm{~h}$, and starter was offered once daily at $0515 \mathrm{~h}$. All animals were weighed twice weekly and blood was sampled once weekly at $0930 \mathrm{~h}$. Blood was collected from the jugular vein into a Vacutainer containing heparin (Becton Dickinson, Franklin Lakes, NJ) and immediately centrifuged at 3,000 $\times g$ for $20 \mathrm{~min}$ and plasma was harvested and stored at $-20^{\circ} \mathrm{C}$ until analysis.

When a calf on the $\mathrm{MR}+\mathrm{S}$ treatment was ready to wean, as indicated by consumption of starter at $680 \mathrm{~g} / \mathrm{d}$ for 3 consecutive days, a small ruminant rumen $\mathrm{pH}$ sensor system (Dascor, Escondido, CA) was orally dosed to a pair of calves ( $\mathrm{MR}+\mathrm{S}$ and $\mathrm{MR}$ calves), rumen $\mathrm{pH}$ was monitored continuously for $3 \mathrm{~d}$ (Laarman and Oba, 2011), and the calves were killed. The 3 -d data collection period allowed for calculation of representative 
average rumen $\mathrm{pH}$ accounting for daily variation while minimizing the risk of $\mathrm{pH}$ sensor failure. A plasma sample was taken as described above at $0930 \mathrm{~h}$ and then both calves within the same block were harvested at 1100 and $1200 \mathrm{~h}$ by stunning by captive bolt gun followed by exsanguination. The order of treatment at harvest was alternated each time; if an $\mathrm{MR}+\mathrm{S}$ calf was killed first on one day, an MR calf was killed first on the next harvest day. A sample of liver tissue was taken from the caudate lobe of the liver and snap frozen in liquid nitrogen. Ruminal epithelial tissue was harvested from the ventral sac of the rumen; the epithelium was manually peeled off from the muscle layer, rinsed in PBS (pH 7.4), and snap-frozen in liquid nitrogen and kept on dry ice. Then, rumen contents were strained through a layer of porous material (Peetex, pore size $=$ 355 m; Sefar Canada Inc., Scarborough, ON, Canada) and rumen fluid was aliquoted in a scintillation vial, snap frozen in liquid nitrogen, and kept on dry ice. Liver tissue, rumen tissue, and rumen fluid were kept at $-80^{\circ} \mathrm{C}$ until analysis.

\section{Sample Analysis}

Calf starter was sampled at the arrival date of each group of calves, dried at $55^{\circ} \mathrm{C}$ for $48 \mathrm{~h}$, ground through a 1-mm screen using a Wiley mill (Thomas-Wiley, Philadelphia, PA), and analyzed for chemical composition. Dry matter content was determined by drying samples at $135^{\circ} \mathrm{C}$ for $2 \mathrm{~h}$ (AOAC, 2002; method 930.15) and $\mathrm{OM}$ was analyzed following a 2-h combustion at $600^{\circ} \mathrm{C}$ (AOAC, 2002; method 942.05). Crude protein content was analyzed using flash combustion (TruSpec analyzer, Leco Corp., St. Joseph, MI; Wrolstad et al., 2004). Starch content was analyzed using an enzymatic method (Karkalas, 1985). Concentration of NDF was analyzed using heat-stable amylase and sodium sulfite as described previously (Van Soest et al., 1991). Ether extract content was analyzed using a Goldfisch extractor (Labconco, Kansas City, MO; Wrolstad et al., 2004).

Plasma samples were analyzed for concentrations of BHBA, insulin, and glucose. Plasma BHBA was analyzed using a $\beta$-hydroxybutyrate dehydrogenase enzyme (Roche, Mannheim, Germany), and glucose was analyzed using a glucoxidase/peroxidase enzyme reaction (Sigma-Aldrich Canada, Oakville, ON, Canada) as described previously (Penner et al., 2009). The BHBA and glucose assays were conducted using a plate reader (SpectraMax, Molecular Devices Inc., Sunnyvale, CA). Insulin concentration was analyzed using a commercial radioimmunoassay kit (Siemens Medical Diagnostics, Los Angeles, CA). The IGF-1 concentration was measured by competitive solid-phase immunoassay based on the method described by Sugino et al. (2004) using hu- man IGF-1 (Novozymes Gropep, Adelaide, Australia), Eu-labeled human IGF-1, polystyrene microtiter strips coated with anti-rabbit $\gamma$-globulin, and anti-human IGF-1 rabbit serum (1:60,000; Novozymes Gropep). The IGF-1 was extracted from plasma by addition of $1 \mathrm{~mL}$ of $1 \mathrm{~N}$ acetic acid (pH 2.0) to $1 \mathrm{~mL}$ of plasma. Plasma protein was precipitated by addition of $4 \mathrm{~mL}$ of acetone. After centrifugation $(1,500 \times g$ for $20 \mathrm{~min}$ at $4^{\circ} \mathrm{C}$ ), the supernatant was evaporated and resuspended in assay buffer (50 $\mathrm{m} M$ Tris- $\mathrm{HCl}, 140 \mathrm{~m} M \mathrm{NaCl}, 0.5 \%$ BSA, $0.05 \% \gamma$-globulins, $0.00078 \%$ diethylene-triaminepentaacetic acid, $0.05 \%$ sodium azide, and $0.01 \%$ Tween 40, pH 7.8) with $10 \mathrm{kIU} / \mathrm{mL}$ of aprotinin. The mean recovery of IGF-1 from bovine plasma, confirmed by dose-response displacement of the IGF- 1 tracer by the addition of bovine plasma, was $98.2 \%$. Intra- and interassay CV were 6.9 and $5.5 \%$, respectively, and the least detectable dose was $0.053 \mathrm{ng} / \mathrm{mL}$.

Rumen fluid samples were thawed and centrifuged at $15,000 \times g$ at $4^{\circ} \mathrm{C}$ to obtain clear supernatant. Concentration of VFA was determined using isocaproic acid as an internal standard with gas chromatography (Varian, Walnut Creek, CA; Penner et al., 2009).

\section{Real-Time PCR}

The RNA was extracted using a Trizol-chloroform (Life Technologies, Burlington, ON, Canada) extraction method (Chomczynski and Sacchi, 1987). After the purity of the RNA was measured with a spectrophotometer (ND-1000, Nanodrop Technologies, Wilmington, DE), $1.6 \mu \mathrm{g}$ of RNA was treated with DNase (Life Technologies) and then reverse-transcribed using Superscript II (Life Technologies) and Oligo-d(T) (Life Technologies). Real-time PCR was performed using Taqman Fast Universal Master Mix (Life Technologies). Primers (Life Technologies) and probes (Life Technologies) were designed using Primer Express v.3.0 (Life Technologies; Table 1) and analyzed by BLAST (http://blast.ncbi.nlm.nih.gov/Blast.cgi) to verify primer specificity. In addition, reverse transcription PCR was performed to verify that each set of primers produced only 1 specific amplicon with the desired size. The target genes were 3 -hydroxy-3-methylglutaryl-CoA synthase isoform 1 (HMGCS-1), 3-hydroxy-3-methylglutaryl-CoA lyase $(\boldsymbol{H} \boldsymbol{M} \boldsymbol{G} \boldsymbol{C L}), \beta$-hydroxybutyrate dehydrogenase, isoforms $1(\boldsymbol{B D H}-\mathbf{1})$ and $2(\boldsymbol{B D H}-2)$, all of which are enzymes involved in butyrate metabolism. The target genes involved in $\mathrm{pH}_{\mathrm{i}}$ were monocarboxylate transporter isoform 1 ( $\boldsymbol{M C T}$-1), putative anion transporter isoform $1(\boldsymbol{P A T}-1)$, downregulated in adenoma $(\boldsymbol{D R} \boldsymbol{A})$, and $\mathrm{Na}^{+} / \mathrm{H}^{+}$exchanger isoforms 1 (NHE-1), 2 (NHE-2), and 3 (NHE-3). In the liver, the target genes for the urea cycle were argininosuc- 
Table 1. Gene names, primer and probe sequences, and accession numbers (National Center for Biotechnology Information) for genes used in real-time PCR analysis

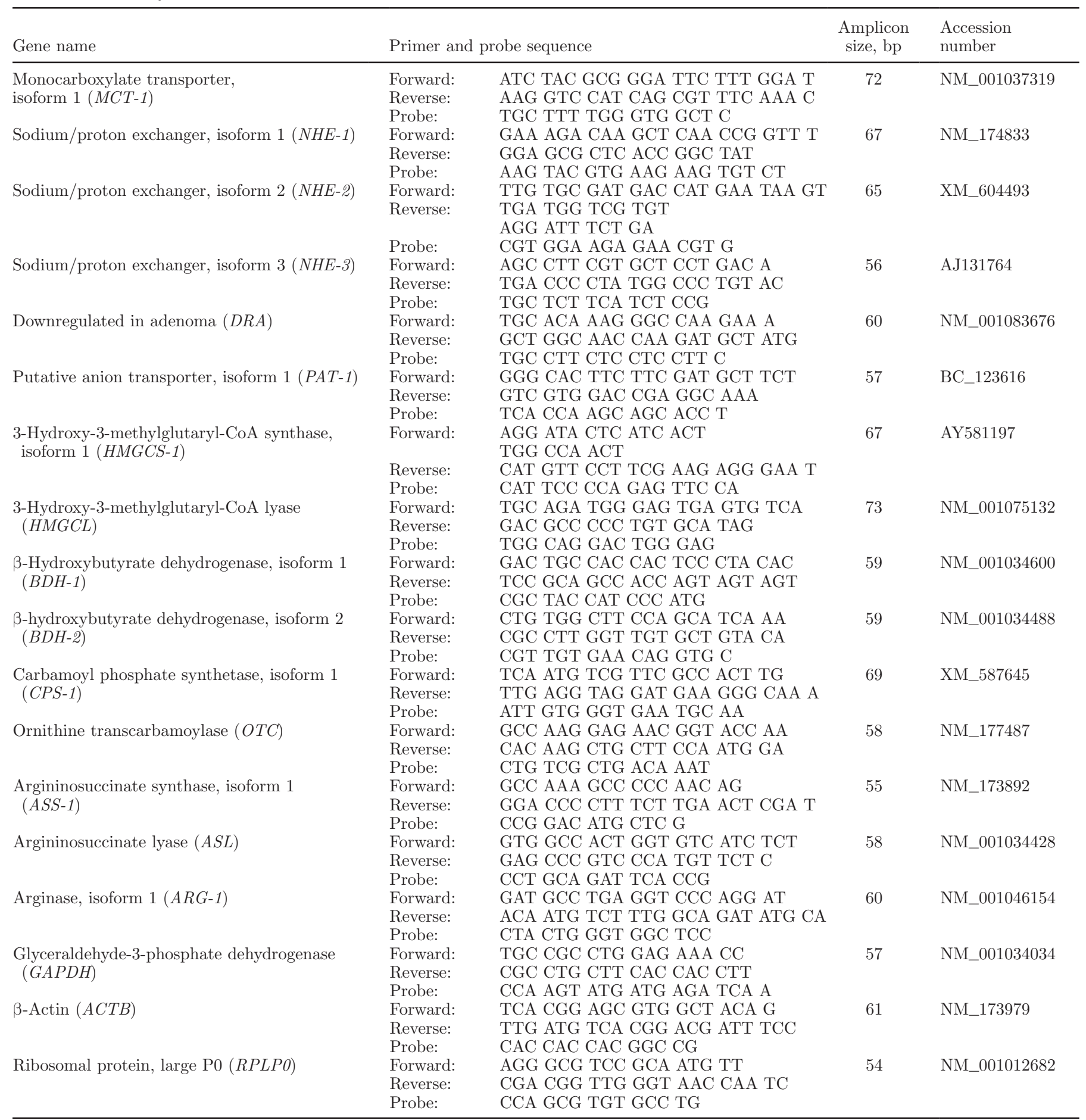

cinate synthase isoform $1(\boldsymbol{A} \boldsymbol{S} \boldsymbol{S}-\mathbf{1})$, argininosuccinate lyase $(\boldsymbol{A S L})$, arginase isoform $1(\boldsymbol{A R G}-\mathbf{1})$, carbamoyl phosphate synthetase isoform $1(\boldsymbol{C P} \boldsymbol{S}-\mathbf{1})$ and ornithine transcarbamoylase $(\boldsymbol{O T C})$. The program used for real- time PCR (StepOnePlus Thermocycler, Life Technologies) was 40 cycles of $95^{\circ} \mathrm{C}$ for $1 \mathrm{~s}$ and $60^{\circ} \mathrm{C}$ for $20 \mathrm{~s}$.

Abundance of mRNA for hepatic target genes was calculated using ribosomal protein large $\mathrm{P} 0(R P L P 0)$ 
as an internal control gene because of its stable expression. For ruminal target genes, as $R P L P 0$ was not sufficiently stably expressed, mRNA abundance was normalized to 3 reference genes: RPLPO, GAPDH, and $\beta$-actin as described previously (Vandesompele et al., 2002). Briefly, all samples from both treatments were analyzed on the same plate for one gene. For each sample, the cycle threshold $\left(\mathrm{C}_{t}\right)$ was calculated and then subtracted from the minimum $\mathrm{C}_{t}$ in the treatment. Then, the relative abundance of mRNA and the normalized mRNA abundance $\left(\mathrm{Q}_{\mathrm{n}}\right)$ were calculated, respectively, by the formulas

$$
\begin{gathered}
\mathrm{Q}=\text { Amplification efficiency }^{\Delta \mathrm{Ct}} \\
\mathrm{Q}_{\mathrm{n}}=\mathrm{Q} / \mathrm{NF}
\end{gathered}
$$

where $\mathrm{NF}$ is the normalization factor, calculated as the geometric average of the $\mathrm{Q}$ values for $G A P D H, \beta$-actin, and $R P L P 0$ for each sample.

\section{Statistics}

Average daily gain was calculated via regression of weekly BW using PROC REG (v. 9.1; SAS Institute Inc., Cary, NC). Data were tested for normality using PROC GLM of SAS. Non-normally distributed data (i.e., BW at harvest) were analyzed by signed rank test. The other data were analyzed as randomized complete block design using PROC MIXED of SAS. Data were expressed as least squares means \pm standard errors. The statistical model used for gene expression and VFA data was

$$
\mathrm{Y}_{\mathrm{ij}}=\mu+\text { Block }_{\mathrm{i}}+\text { Treatment }_{\mathrm{j}}+\mathrm{e}_{\mathrm{ij}},
$$

where $Y_{i j}$ is a response variable, $\mu$ is the overall mean, Block $_{\mathrm{i}}$ is the effect of blocking by age and starting date, Treatment $_{\mathrm{j}}$ is the effect of $\mathrm{MR}$ or $\mathrm{MR}+\mathrm{S}$ treatment, and $e_{i j}$ is the residual error.

Hay intake was originally included as a covariate, but was found to have no effect on the outcome, so it was dropped from the model. For weekly blood plasma metabolites, the statistical model was

$$
\begin{aligned}
\mathrm{Y}_{\mathrm{ijk}}= & \mu+\text { Block }_{\mathrm{i}}+\text { Treatment }_{\mathrm{j}}+\text { Week }_{\mathrm{k}} \\
& + \text { Treatment } \times \text { Week }_{\mathrm{jk}}+\mathrm{e}_{\mathrm{ijk}},
\end{aligned}
$$

where $Y_{\mathrm{ijk}}$ is a response variable, $\mu$ is the overall mean, Block $_{\mathrm{i}}$ is the effect of block by age and starting date, Treatment $_{\mathrm{j}}$ is the effect of $\mathrm{MR}$ or $\mathrm{MR}+\mathrm{S}$ treatment, Week $_{\mathrm{k}}$ is the effect of week in age as a repeated measure, Treatment $\times \mathrm{Week}_{\mathrm{jk}}$ is the treatment by week interaction, and $e_{i j k}$ is the residual error. Significance was declared at $P<0.05$ and tendency of treatment effects were declared at $P<0.10$. Due to a recurring respiratory illness, one block of animals had to be removed from the trial and was not included in statistical analysis.

\section{RESULTS}

\section{Growth and Blood Metabolites}

Age of calves at slaughter did not differ between $\mathrm{MR}$ and $\mathrm{MR}+\mathrm{S}$ (49.6 vs. $50.0 \mathrm{~d} ; P=0.45$; Table 2). Average daily gain did not differ between $M R$ and $\mathrm{MR}+\mathrm{S}(0.80$ vs. $0.86 \mathrm{~kg} / \mathrm{d} ; P=0.45)$, and treatment had no effect on final BW $(P=0.30)$. Plasma insulin concentration was also not affected by treatment $(P$ $=0.23$ ), although plasma insulin increased between 6 and 8 wk of life, increasing from 25.2 to $92.2 \mu \mathrm{IU} / \mathrm{mL}$ $(P<0.01 ;$ Figure 1$)$. No treatment by time interaction existed for plasma insulin $(P=0.16)$. Plasma BHBA concentration was not affected by treatment $(P=0.53)$ or by time $(P=0.65$; Figure 2$)$, and we observed no treatment by time interaction $(P=0.62)$. Treatments did not differ in plasma glucose $(P=0.38)$, although plasma glucose increased between 6 and 8 wk of life $(P$ $<0.01$; Figure 3); no treatment by time interaction was found $(P=0.86)$. Plasma IGF-1 concentrations did not differ between treatments $(P=0.40$; Figure 4$)$, but differed with time $(P<0.01)$. At harvest, plasma glucose and plasma BHBA did not differ with treatment, but plasma insulin was higher in the MR calves (146.4 vs. $47.9 \mu \mathrm{IU} / \mathrm{mL} ; P=0.02$; Table 3$)$ than in the $\mathrm{MR}+\mathrm{S}$ calves.

\section{Rumen Fermentation}

The $\mathrm{MR}+\mathrm{S}$ treatment altered the VFA profile in the rumen fluid (Table 3). The $\mathrm{MR}+\mathrm{S}$ calves had a lower molar proportion of acetate (57.6 vs. $69.3 \% ; P<0.01$ ), a higher molar proportion of butyrate (15.6 vs. $7.9 \% ; P$ $=0.03$ ), and a higher total VFA concentration (99.1 vs. $64.6 \mathrm{mM} ; P<0.01)$ than MR calves.

\section{Rumen Epithelium and Liver Gene Expression}

Abundance of mRNA was calculated as a relative value with arbitrary units. The mRNA abundance was higher for $M C T-1$ (1.45 vs. $0.53 ; P<0.01$; Table 4) and lower for NHE-3 (0.37 vs. $0.82 ; P<0.01)$ and HMGCS-1 (0.40 vs. $0.94 ; P=0.01)$ in the $\mathrm{MR}+\mathrm{S}$ calves compared with the MR calves (Table 4). Relative mRNA abundance of DRA, NHE-1, NHE-2, HMGCL, $B D H-1$, and $B D H-2$ were not affected by treatment. 


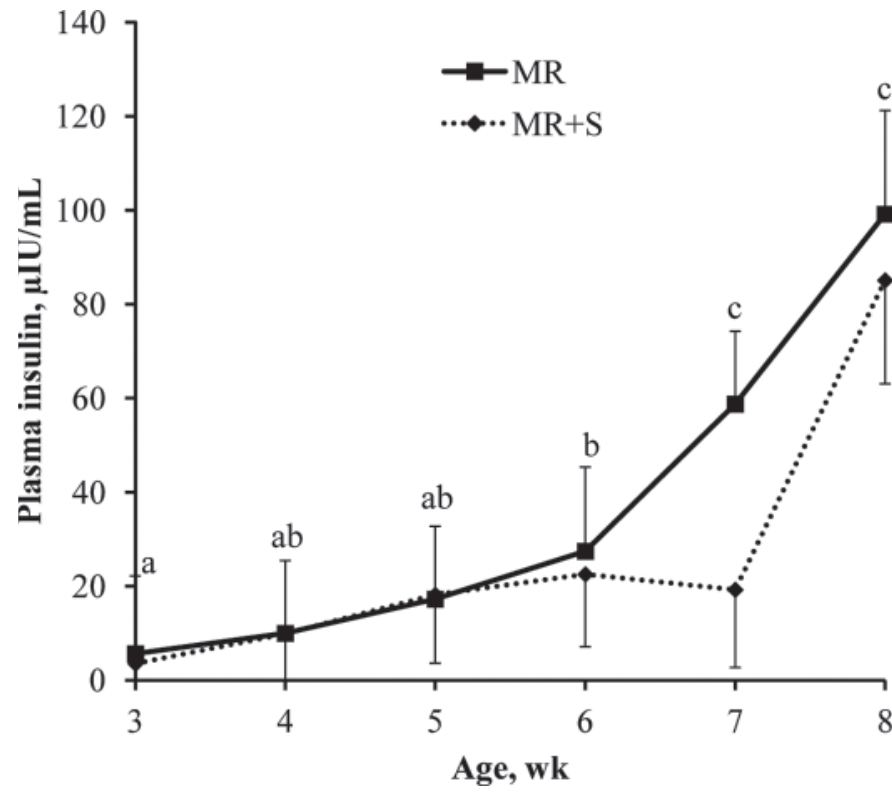

Figure 1. Plasma insulin concentrations between 3 and 8 wk of age in Holstein bull calves fed milk replacer and hay without calf starter $(\mathrm{MR})$ or with calf starter ad libitum $(\mathrm{MR}+\mathrm{S})$. Treatment did not affect plasma insulin levels over time $(P=0.23)$ and no interaction was observed between treatment and week of life $(P=0.16)$. Letters denote significant differences between weeks $(P<0.01)$.

In the livers of calves fed calf starter, genes encoding $A S S-1, A S L$, and $A R G-1$ had higher mRNA abundance than in the MR treatment (Table 5).

\section{DISCUSSION}

\section{Calf Starter-Dependent Adaptations}

Rumen. Greater VFA concentrations in $\mathrm{MR}+\mathrm{S}$ than in MR calves is consistent with expected greater fermentation in the rumen of $\mathrm{MR}+\mathrm{S}$ claves. Although leakage of milk from the esophageal groove may cause some fermentation of milk in the rumen, it is unlikely to be a major contributor to total rumen fermentation,

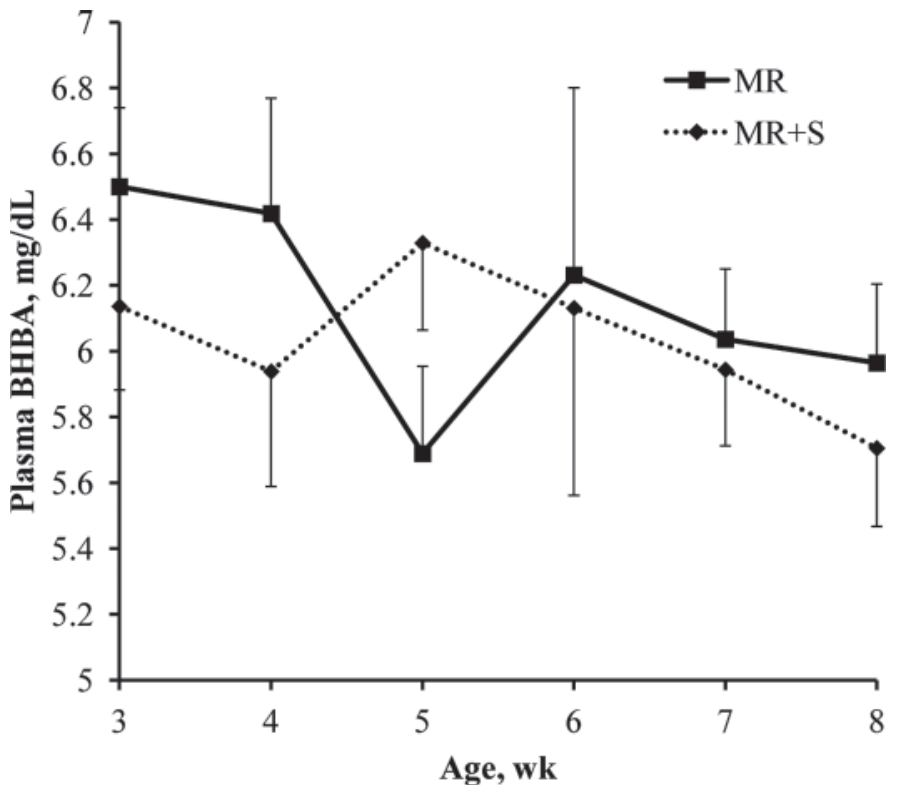

Figure 2. Plasma BHBA concentrations between 3 and 8 wk of age in Holstein bull calves fed milk replacer and hay without calf starter $(\mathrm{MR})$ or with calf starter ad libitum $(\mathrm{MR}+\mathrm{S})$. Treatment did not affect plasma BHBA concentrations $(P=0.53)$. Between 3 and 8 wk of life, no statistical difference in average weekly plasma BHBA concentrations was found $(P=0.65)$ and no treatment $\times$ week interaction was found $(P=0.62)$.

as esophageal groove failure has been shown to be in the order of several milliliters of milk per feeding (Wise and Anderson, 1939). As such, responses in mRNA abundance in the rumen epithelium and the liver are likely attributed to fermentation of calf starter in the rumen of $\mathrm{MR}+\mathrm{S}$ calves.

One particular gene of interest is apical $N H E-3$, an apical membrane sodium-proton anti-porter involved in regulation of intracellular pH (Malo and Fliegel, 2006). The expression of NHE-3 is up-regulated by butyrate (Kiela et al., 2007), whereas long-term regulation of NHE-3 is primarily accomplished through changes in transcription (Zachos et al., 2005). In disagreement

Table 2. Average daily gain and BW at harvest and average plasma metabolite concentrations of Holstein bull calves fed calf starter ad libitum with milk replacer and hay $(\mathrm{MR}+\mathrm{S})$, and those fed milk replacer and hay only (MR)

\begin{tabular}{lccc}
\hline Item & $\mathrm{MR}$ & $\mathrm{MR}+\mathrm{S}$ & $P$-value \\
\hline Final age, $\mathrm{d}$ & $49.6 \pm 3.3$ & $50.0 \pm 3.3$ & 0.45 \\
$\mathrm{ADG}, \mathrm{kg} / \mathrm{d}$ & $0.86 \pm 0.07$ & $0.80 \pm 0.08$ & 0.45 \\
$\mathrm{BW}, \mathrm{kg}$ & $78.4 \pm 3.0$ & $76.8 \pm 3.5$ & 0.30 \\
Plasma insulin, ${ }^{1}{ }^{\mu \mathrm{IU} / \mathrm{mL}}$ & $57.6 \pm 14.7$ & $31.1 \pm 14.7$ & 0.23 \\
Plasma glucose, ${ }^{1} \mathrm{mg} / \mathrm{dL}$ & $106.6 \pm 7.0$ & $98.5 \pm 7.0$ & 0.38 \\
Plasma BHBA, $\mathrm{mg} / \mathrm{dL}$ & $6.2 \pm 0.1$ & $6.1 \pm 0.2$ & 0.53 \\
Plasma IGF- $1,{ }^{1} \mathrm{ng} / \mathrm{mL}$ & $80.0 \pm 8.4$ & $76.2 \pm 7.9$ & 0.74 \\
PUN, ${ }^{1,2} \mathrm{mg} / \mathrm{dL}$ & $4.3 \pm 0.3$ & $5.6 \pm 0.3$ & 0.01 \\
\hline
\end{tabular}

${ }^{1}$ Average concentration between wk 3 and 8 of age.

${ }^{2}$ Plasma urea nitrogen. 


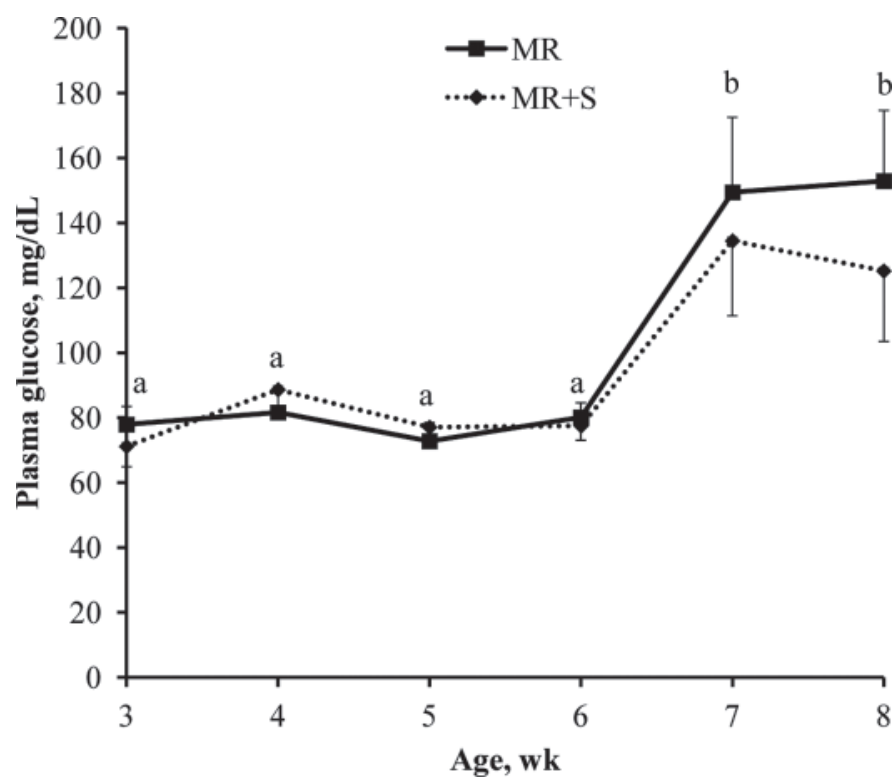

Figure 3. Plasma glucose concentrations between 3 and 8 wk of age in Holstein bull calves fed milk replacer and hay without calf starter $(\mathrm{MR})$ or with calf starter ad libitum $(\mathrm{MR}+\mathrm{S})$. Plasma glucose was not affected by treatment $(P=0.38)$. Average plasma glucose did increase significantly between wk 6 and 7 of life $(P<0.01)$, but no treatment $\times$ week interaction $(P=0.86)$ was observed. Weekly averages with different letters are significantly different.

with findings of Kiela et al. (2007), abundance of NHE3 mRNA was lower in the $\mathrm{MR}+\mathrm{S}$ treatment despite a higher butyrate concentration in rumen fluid. The reason for lower NHE-3 mRNA abundance in rumen epithelia from the $\mathrm{MR}+\mathrm{S}$ calves is not known, but lower NHE-3 expression may indicate decreased proton recycling into the lumen and greater net proton uptake by ruminal epithelium for the $\mathrm{MR}+\mathrm{S}$ calves. Lower

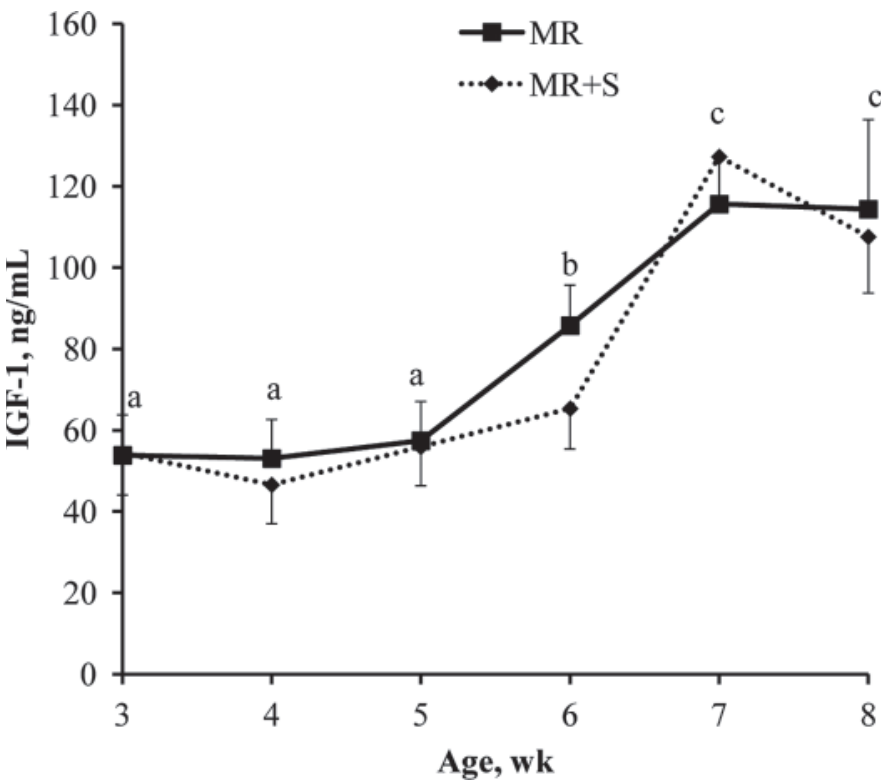

Figure 4. Plasma IGF-1 concentrations between 3 and 8 wk of age in Holstein bull calves fed milk replacer and hay without calf starter $(\mathrm{MR})$ or with calf starter ad libitum $(\mathrm{MR}+\mathrm{S})$. Plasma glucose was not affected by treatment $(P=0.74)$. Average plasma IGF-1 did increase significantly between wk 6 and 7 of life $(P<0.01)$, but no treatment $\times$ week interaction $(P=0.40)$ was observed. Weekly averages with different letters are significantly different.

proton recycling into the rumen (and thus greater net proton uptake) in the $\mathrm{MR}+\mathrm{S}$ treatment may explain why rumen $\mathrm{pH}$ did not differ (Laarman and Oba, 2011) in spite of greater VFA concentrations for $\mathrm{MR}+\mathrm{S}$ treatment.

Increased expression of $M C T-1$, located on the basolateral membrane (Connor et al., 2009), in MR+S supports the idea that net proton absorption may be

Table 3. Rumen VFA profile ${ }^{1}$ and blood plasma metabolites ${ }^{2}$ on the day of harvest in Holstein bull calves fed milk and hay only $(\mathrm{MR})$ or calf starter ad libitum, milk, and hay $(\mathrm{MR}+\mathrm{S})$ at the start of weaning

\begin{tabular}{lcrr}
\hline Item & MR & MR+S & $P$-value \\
\hline Total VFA, mM & $64.6 \pm 8.6$ & $99.1 \pm 8.1$ & $<0.01$ \\
Acetate, mol/100 mol of VFA & $69.3 \pm 1.9$ & $57.6 \pm 1.9$ & $<0.01$ \\
Propionate, mol/100 mol of VFA & $18.7 \pm 1.3$ & $21.3 \pm 1.2$ & 0.32 \\
Butyrate, mol/100 mol of VFA & $7.9 \pm 1.9$ & $15.6 \pm 1.7$ & 0.03 \\
Plasma glucose, mg/dL & $84.5 \pm 5.5$ & $84.2 \pm 5.5$ & 0.97 \\
Plasma BHBA, mg/dL & $7.6 \pm 0.4$ & $7.1 \pm 0.4$ & 0.33 \\
Plasma insulin, $\mu \mathrm{IU} / \mathrm{mL}$ & $146.4 \pm 26.7$ & $47.9 \pm 28.6$ & 0.02 \\
Plasma IGF-1, ng/mL & $246.3 \pm 25.2$ & $216.5 \pm 23.6$ & 0.36 \\
NH$_{3}-\mathrm{N}, \mathrm{mg} / \mathrm{dL}$ & $11.7 \pm 2.1$ & $4.9 \pm 2.1$ & 0.06 \\
Log(PUN), 3 mg/dL & $0.33 \pm 0.08$ & $0.73 \pm 0.08$ & $<0.01$ \\
PUN, ${ }^{3,5} \mathrm{mg} / \mathrm{dL}$ & $2.14 \pm 1.20$ & $5.37 \pm 1.20$ & $\mathrm{NA}$ \\
\hline
\end{tabular}

${ }^{1}$ Sampled $6 \mathrm{~h}$ after morning feeding.

${ }^{2}$ Sampled $4 \mathrm{~h}$ after morning feeding.

${ }^{3}$ Plasma urea nitrogen.

${ }^{4}$ Statistical analyses were performed on log-transformed, normally distributed data.

${ }^{5}$ Reverse-transformed values are shown for reader convenience. 
Table 4. Abundance of $\mathrm{mRNA}^{1,2}$ involved in intracellular $\mathrm{pH}$ regulation and butyrate metabolism in the rumen epithelium of Holstein bull calves fed milk replacer and hay only (MR) or milk replacer, hay, and ad libitum calf starter $(\mathrm{MR}+\mathrm{S})$

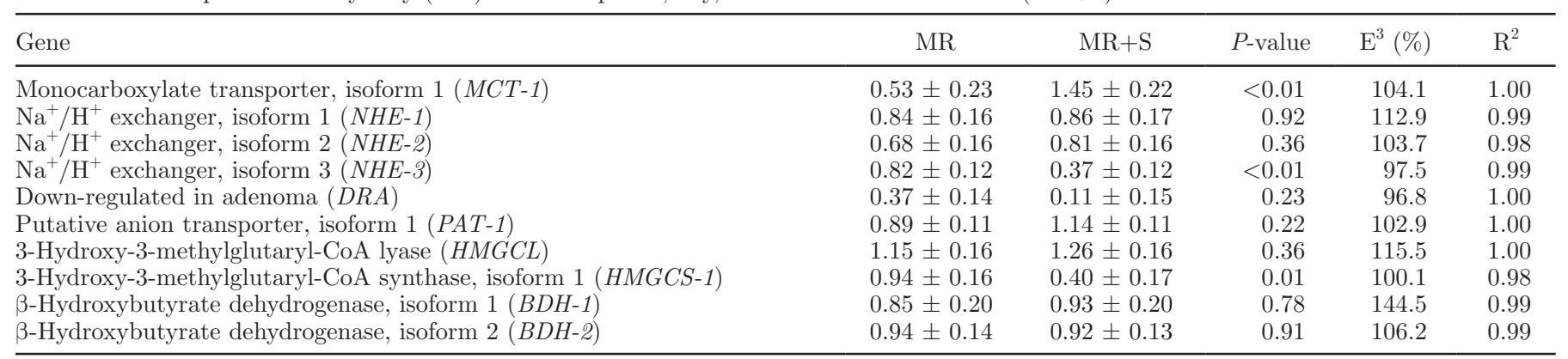

${ }^{1}$ Relative to the sample with the highest abundance (lowest cycle threshold); values were normalized by geometric means of non-normalized mRNA abundance of 3 reference genes (glyceraldehyde-3-phosphate dehydrogenase, $\beta$-actin, and ribosomal protein large P0).

${ }^{2} \mathrm{n}=18$.

${ }^{3}$ Efficiency of amplification.

higher in $\mathrm{MR}+\mathrm{S}$. Because $M C T-1$ is a monocarboxylate $/ \mathrm{H}^{+}$co-transporter, it contributes to proton removal from the ruminal epithelium to the blood circulation (Meredith and Christian, 2008). The increased expression of MCT-1 appears to complement the decreased expression of NHE-3 and may increase net proton removal from the rumen.

Cholesterol synthesis also appears to be affected by diet. Specifically, HMGCS-1 has been shown to be down-regulated in mature nonlactating dairy cows switched to a high-grain diet from a high forage diet, possibly to mitigate excess cellular cholesterol (Steele et al., 2011). Further, increased supply of VFA in vitro caused the downregulation of 9 genes involved in cholesterol synthesis in a Caco-2/TC-7 cell line (Alvaro et al., 2008). In our study, the $\mathrm{MR}+\mathrm{S}$ treatment was associated with lower mRNA abundance of $H M G C S-1$, suggesting that provision of calf starter might downregulate cholesterol synthesis at the mRNA level.

Liver. Of all genes involved in the urea cycle, mRNA abundance of $C P S-1$ was not different between treatments and that of $O T C$ tended to be higher for the $\mathrm{MR}+\mathrm{S}$ treatment. In growing Holstein calves, $C P S-1$ mRNA abundance did not increase between 2 and 19 wk of age, but carbamoyl phosphate synthetase activity did (Takagi et al., 2008), suggesting that activity of $C P S-1$ may not be regulated by transcription. The remaining genes in the urea cycle, $A S L, A S S-1$, and $A R G-1$, had greater abundance of mRNA in $\mathrm{MR}+\mathrm{S}$ than in MR calves, which is consistent with greater plasma urea $\mathrm{N}$ concentration for calves fed a calf starter. Previous work showed that the mRNA abundance of $A S L$ and $A R G-1$ decreased, whereas activity of $O T C$, $A S L$, and $A S S-1$ increased with age in Holstein calves (Takagi et al., 2008). Urea production has been shown to be dependent on nitrogen intake in steers across a range of high-forage and high-concentrate diets (Huntington and Archibeque, 2000). As such, greater plasma urea $\mathrm{N}$ for the $\mathrm{MR}+\mathrm{S}$ calves might be also attributed to their higher $\mathrm{N}$ intake compared with the MR calves.

\section{Calf Starter-Independent Adaptations}

Plasma IGF-1, insulin, BHBA, and glucose concentrations appeared to be not related to calf starter fermentation as none of these parameters were affected by treatment between wk 3 and 8. Although plasma glucose did not differ between treatments, plasma glucose

Table 5. Abundance of $\mathrm{mRNA}^{1,2}$ involved in the urea cycle in the liver of Holstein bull calves fed milk replacer and hay only (MR) or milk replacer, hay, and ad libitum calf starter $(\mathrm{MR}+\mathrm{S})$

\begin{tabular}{lcrrrr}
\hline Gene & $\mathrm{MR}$ & $\mathrm{MR}+\mathrm{S}$ & $P$-value & $\mathrm{E}^{3}(\%)$ & $\mathrm{R}^{2}$ \\
\hline Carbamoyl phosphate synthetase $(C P S)$ & $8.67 \pm 1.10$ & $9.90 \pm 1.10$ & 0.45 & 98.1 & 0.99 \\
Ornithine transcarbamoylase (OTC) & $1.34 \pm 0.11$ & $1.64 \pm 0.11$ & 0.08 & 101.3 \\
Arginosuccinate synthetase, isoform 1 (ASS-1) & $1.56 \pm 0.29$ & $2.67 \pm 0.29$ & 0.03 & 99.8 & 0.99 \\
Arginosuccinate lyase $(A S L)$ & $0.99 \pm 0.10$ & $1.44 \pm 0.10$ & 0.02 & 98.6 & 0.99 \\
Arginase, isoform 1 (ARG-1) & $1.74 \pm 0.32$ & $3.21 \pm 0.32$ & 0.01 & 99.7 & 0.99 \\
\hline
\end{tabular}

${ }^{1}$ Relative to the sample with the highest abundance (lowest cycle threshold); values were normalized by geometric means of non-normalized mRNA abundance of ribosomal protein large P0.

${ }^{2} \mathrm{n}=18$.

${ }^{3}$ Efficiency of amplification. 
increased between 6 and 7 wk of age to approximately $110 \mathrm{mg} / \mathrm{dL}$, regardless of treatment, which is nearly double the concentration found in lactating dairy cows (Silveira et al., 2007). We observed a significant effect of age on plasma IGF-1, insulin, and glucose, but not BHBA, concentrations. The lack of change in plasma BHBA concentrations over time agrees with previous findings that plasma BHBA concentration is not dependent on diet or energy intake (Lane et al., 2000). Previous studies have shown plasma BHBA concentrations in lambs to be low (Baldwin and Jesse, 1992) or nondetectable (Lane et al., 2000) until $42 \mathrm{~d}$ of age, at which point plasma BHBA concentrations increase. In our study, increases in plasma concentrations were not detected for BHBA, but were detected for IGF-1, glucose, and insulin. Although energy intake increased steadily from wk 3 to 8 of life, plasma IGF-1, glucose, and insulin concentrations spiked between 6 and $8 \mathrm{wk}$ of life, suggesting that plasma IGF-1, plasma glucose, and plasma insulin, before weaning, appear to be affected by age or energy intake rather than diet type.

\section{Implications for Nutritional Management}

The conventional recommendation in nutritional management for dairy calves is to wean calves as soon as starter intake is above $680 \mathrm{~g} / \mathrm{d}$, as early as $4 \mathrm{wk}$ of age (NRC, 2001). The increased mRNA abundance of hepatic urea cycle enzymes in $\mathrm{MR}+\mathrm{S}$ shows that provision of calf starter may help enhance the urea cycle before weaning. Furthermore, changes in regulation of MCT-1 and NHE-3 in the rumen epithelium suggest that the rumen epithelium may be adapting to increase VFA absorption, which is the primary mode of acid removal from the rumen (Allen, 1997). Provision of calf starter has been shown to have substantial effects on the rumen epithelium and the liver and may be important in metabolically preparing a calf for weaning. It is important to note, however, that gene expression does not imply protein expression or activity, which limits the scope of the current study.

As for age of weaning, our results showed that plasma IGF-1 and insulin concentrations did not increase until 7 wk of age, and thus very early weaning may not be beneficial if calves are not metabolically ready for weaning. When weaning is initiated at 3 wk of age, calves are not able to compensate for decreased milk intake by increasing starter intake (Sweeney et al., 2010), resulting in decreased intake of digestible energy. Delays in weaning until 12 to 13 wk of age effectively eliminate the decreases in digestible energy intake that are typical in calves weaned early (de Passillé et al., 2011), suggesting that weaning age affects the metabolic capability of calves to adapt to solid feed. The lack of treatment effect on the plasma metabolites measured in the current study indicated that some metabolic adaptations might not be induced by consumption of solid feed per se. As such, calf starter intake may not be used as the sole indicator to determine whether calves are ready for weaning.

\section{CONCLUSIONS}

Calf starter fermentation in preweaned Holstein calves alters expression of genes involved in $\mathrm{pH}_{\mathrm{i}}$ regulation and $H M G C S-1$ in the rumen epithelium, and mRNA abundance of urea cycle enzymes in the liver. Although the liver and rumen epithelium responded to calf starter feeding at the level of gene transcription, plasma concentrations of IGF-1, glucose, insulin, and BHBA did not appear to be affected by calf starter fermentation. Plasma IGF-1, glucose, and insulin concentrations may be influenced by age or energy intake to a greater extent than diet type.

\section{ACKNOWLEDGMENTS}

The authors thank the staff at the Metabolic Unit (University of Alberta) for their assistance and F. Bruijnen and B. Wiese (of the University of Alberta, Edmonton, AB, Canada) for technical assistance. The authors also acknowledge funding from the Natural Sciences and Engineering Research Council (Ottawa, ON, Canada), Zen-Raku-Ren (Japanese Federation of Dairy Cooperative Associations, Tokyo, Japan) and a graduate scholarship from the Canadian Dairy Commission (Ottawa, ON, Canada).

\section{REFERENCES}

Allen, M. S. 1997. Relationship between fermentation acid production in the rumen and the requirement for physically effective fiber. J. Dairy Sci. 80:1447-1462.

Alvaro, A., R. Solà, R. Rosales, J. Ribalta, A. Anguera, L. Masana, and J. C. Vallvé. 2008. Gene expression analysis of a human enterocyte cell line reveals downregulation of cholesterol biosynthesis in response to short-chain fatty acids. Life 60:757-764.

AOAC. 2002. Official Methods of Analysis. Vol. 1. 17th ed. Association of Official Analytical Chemists, Arlington, VA.

Baldwin, R. L. VI, and B. W. Jesse. 1992. Developmental changes in glucose and butyrate metabolism by isolated sheep rumen epithelial cells. J. Nutr. 122:1149-1153.

Chomczynski, P., and N. Sacchi. 1987. Single-step method of RNA isolation by acid guanidinium thiocyanate-phenol-chloroform extraction. Anal. Biochem. 162:156-159.

Connor, E. E., R. W. Li, R. L. Baldwin, and C. Li. 2009. Gene expression in the digestive tissues of ruminants and their relationships with feeding and digestive processes. Animal 4:993-1007.

de Passillé, A. M., T. F. Borderas, and J. Rushen. 2011. Weaning age of calves fed a high milk allowance by automated feeders: Effects on feed, water, and energy intake, behavioral signs of hunger, and weight gains. J. Dairy Sci. 94:1401-1408. 
Hugi, D., and J. W. Blum. 1997. Changes of blood metabolites and hormones in breeding calves associated with weaning. Zentralbl. Veterinarmed. A 44:99-108.

Huntington, G. B., and S. L. Archibeque. 2000. Practical aspects of urea and ammonia metabolism in ruminants. J. Anim. Sci. 77:111 .

Karkalas, J. 1985. An improved enzymic method for the determination of native and modified starch. J. Sci. Food Agric. 36:1019-1027.

Kiela, P. R., N. Kuscuoglu, A. J. Midura, M. T. Midura-Kiela, C. B Larmonier, M. Lipko, and F. K. Ghishan. 2007. Molecular mechanism of rat NHE3 gene promoter regulation by sodium butyrate. Am. J. Physiol. Cell Physiol. 293:C64-C74.

Laarman, A. H., and M. Oba. 2011. Short communication: Effect of calf starter on rumen $\mathrm{pH}$ of Holstein dairy calves at weaning. J Dairy Sci. 94:5661-5664.

Lane, M. A., R. L. Baldwin VI, and B. W. Jesse. 2000. Sheep rumen metabolic development in response to age and dietary treatments. J. Anim. Sci. 78:1990-1996.

Lane, M. A., R. L. Baldwin VI, and B. W. Jesse. 2002. Developmental changes in ketogenic enzyme gene expression during sheep rumen development. J. Anim. Sci. 80:1538-1544.

Malo, M. E., and L. Fliegel. 2006. Physiological role and regulation of the $\mathrm{Na}^{+} / \mathrm{H}^{+}$exchanger. Can. J. Physiol. Pharmacol. 84:10811095.

Meredith, D., and H. C. Christian. 2008. The SLC16 monocarboxylate transporter family. Xenobiotica 38:1072-1106.

Nocek, J. E. 1997. Bovine acidosis: Implications on laminitis. J. Dairy Sci. 80:1005-1028.

NRC (National Research Council). 2001. Nutrient Requirements of Dairy Cattle. 7th ed. National Academy Press, Washington, DC.

Penner, G. B., M. Taniguchi, L. L. Guan, K. A. Beauchemin, and M. Oba. 2009. Effect of dietary forage to concentrate ratio on volatile fatty acid absorption and the expression of genes related to volatile fatty acid absorption and metabolism in ruminal tissue. J. Dairy Sci. $92: 2767-2781$

Rémond, D., I. Ortigues, and J. P. Jouany. 1995. Energy substrates for the rumen epithelium. Proc. Nutr. Soc. 54:95-105.

Sander, E. G., R. G. Warner, H. N. Harrison, and J. K. Loosli. 1959 The stimulatory effect of sodium butyrate and sodium propionate on the development of rumen mucosa in the young calf. J. Dairy Sci. 42:1600-1605.

Silveira, C., M. Oba, K. A. Beauchemin, and J. Helm. 2007. Effect of grains differing in expected ruminal fermentability on the productivity of lactating dairy cows. J. Dairy Sci. 90:2852-2859.
Steele, M. A., G. Vandervoort, O. AlZahal, S. E. Hook, J. C. Matthews, and B. W. McBride. 2011. Rumen epithelial adaptation to high-grain diets involves the coordinated regulation of genes involved in cholesterol homeostasis. Physiol. Genomics 43:308-316.

Stobo, I. J. F., J. H. B. Roy, and H. J. Gaston. 1966. Rumen development in the calf. Br. J. Nutr. 20:189-215.

Sugino, T., Y. Hasegawa, Y. Kurose, M. Kojima, K. Kangawa, and Y. Terashima. 2004. Effects of ghrelin on food intake and neuroendocrine function in sheep. Anim. Reprod. Sci. 82-83:183-194.

Sweeney, B. C., J. Rushen, D. M. Weary, and A. M. de Passillé. 2010. Duration of weaning, starter intake, and weight gain of dairy calves fed large amounts of milk. J. Dairy Sci. 93:148-152.

Takagi, M., T. Yonezawa, S. Haga, H. Shingu, Y. Kobayashi, T. Takahashi, Y. Ohtani, Y. Obara, and K. Katoh. 2008. Changes of activity and mRNA expression of urea cycle enzymes in the liver of developing Holstein calves. J. Anim. Sci. 86:1526-1532.

Van Soest, P. J., J. B. Robertson, and B. A. Lewis. 1991. Methods for dietary fiber, neutral detergent fiber, and nonstarch polysaccharides in relation to animal nutrition. J. Dairy Sci. 74:3583-3597.

Vandesompele, J., K. De Preter, F. Pattyn, B. Poppe, N. Van Roy, A. De Paepe, and F. Speleman. 2002. Accurate normalization of real-time quantitative RT-PCR data by geometric averaging of multiple internal control genes. Genome Biol. 3:0034.0031.

Walker, D. M., and G. J. Walker. 1961. The development of the digestive system of the young animal. V. The development of rumen function in the young lamb. J. Agric. Sci. 57:271-278.

Warner, R. G., W. P. Flatt, and J. K. Loosli. 1956. Ruminant nutrition, dietary factors influencing development of ruminant stomach. J. Agric. Food Chem. 4:788-792.

Wise, G. H., and G. W. Anderson. 1939. Factors affecting the passage of liquids into the rumen of the dairy calf. I. Method of administering liquids: Drinking from open pail versus sucking through a rubber nipple. J. Dairy Sci. 22:697-705.

Wrolstad, R. E., E. A. Decker, S. J. Schwartz, and P. Sporns. 2004 Handbook of Food Analytical Chemistry: Water, Proteins, Enzymes, Lipids and Carbohydrates. Vol. 1. John Wiley and Sons, Hoboken, NJ.

Zachos, N. C., M. Tse, and M. Donowitz. 2005. Molecular physiology of intestinal $\mathrm{Na}^{+} / \mathrm{H}^{+}$exchange. Annu. Rev. Physiol. 67:411-443. 